\title{
A comparative histochemical study of the distribution of mucins in the gastrointestinal tracts of three insectivorous mammals
}

\author{
Julia Boonzaier ${ }^{\mathrm{a}}$, Elizabeth L. Van der Merwe ${ }^{\mathrm{b}}$, Nigel C. Bennett ${ }^{\mathrm{c}}$, Sanet H. Kotzéa,** \\ a Department of Biomedical Sciences, Faculty of Health Sciences, University of Stellenbosch, Tygerberg 7505, South Africa \\ ${ }^{\mathrm{b}}$ Department of Human Biology, Faculty of Health Sciences, University of Cape Town, Observatory 7925, South Africa \\ ${ }^{\mathrm{c}}$ Department of Zoology and Entomology, Mammal Research Institute, University of Pretoria, Pretoria 0002, South Africa
}

Keywords:

Mucins

Gastrointestinal tract

Histochemistry

Insectivores

\begin{abstract}
A B S T R A C T
The distribution of mucous secreting goblet cells was examined in the gastrointestinal tracts of three insectivores namely: Acomys spinosissimus (Southern African spiny mouse), Crocidura cyanea (Reddish gray musk shrew) and Amblysomus hottentotus (Hottentot golden mole) in order to improve our understanding of the quality and composition of the protective intestinal biofilm. Intestinal tracts were fixed and processed to wax for histology. Serial transverse sections were stained using alcian blue-periodic acid Schiff, alcian blue-aldehyde fuchsin and alcian blue-high iron diamine techniques. Photomicrographs of the stained sections were analyzed by quantifying the number of goblet cells containing mucins per $\mathrm{mm}^{2}$ in the surface epithelial or crypt areas. Neutral mucins predominated in the gastric epithelium of all three insectivores, while sialomucins were absent in the stomach of $C$. cyanea. In all three species, goblet cells producing a mixture of neutral and acid mucins were most abundant throughout the intestinal tract as were cells secreting a mixture of sulfomucins and sialomucins. However, differences between the insectivore species were observed in the qualitative expression and distribution of mucins throughout the intestinal tract. Similarities between the insectivores of this study and other distantly related species suggest that mixed mucin goblet cells are essential for the formation of the biofilm, irrespective of their diet or taxonomy.
\end{abstract}

\section{Introduction}

The entire gastrointestinal (GI) mucosal surface from the stomach to the colon is covered with a mucous layer (Atuma et al., 2001). The mucous layer is a viscoelastic gel that lubricates the intestinal mucosa and protects the epithelial layer from mechanical damage and pathogen invasion (Forstner and Forstner, 1994; Montagne et al., 2004; Pavelka and Roth, 2010). This mucous layer also provides a microenvironment for indigenous microflora resulting in the formation of a biofilm on the mucosal surface, which plays an essential role in the gastrointestinal tract (GIT) health of individuals (Probert and Gibson, 2002; Corfield and Shukla, 2003).

Defects in the mucosal barrier system and mucin structure become evident when the normal microflora, the mucous layer or the epithelial cells are disturbed by pathogens, antigens and other toxic substances from the gut lumen (Montagne et al., 2004; Pearson and Brownlee, 2005). These changes alter the properties

\footnotetext{
* Corresponding author at: Department of Biomedical Sciences, Faculty of Health Sciences, University of Stellenbosch, P.O. Box 19063, Tygerberg 7505, South Africa. E-mail address: shk@sun.ac.za (S.H. Kotzé).
}

of the viscous mucous gel and influence the interactions of mucins with micro-organisms and defensive proteins, therefore reducing the protective abilities of the mucous layer (Raouf et al., 1992). Inflammatory bowel diseases (IBDs) such as Crohn's disease and ulcerative colitis are associated with defective MUC genes causing an altered mucosal barrier (McAuley et al., 2007; McGuckin et al., 2007).

Mucus is a constantly changing mixture of many secretions and exfoliated epithelial cells. The main determinants of the functional and physical properties of mucus are highly glycosylated, high molecular weight proteins, named mucins (Forstner and Forstner, 1994). Mucin granules are synthesized and secreted by specialized goblet cells in the GIT, located on the mucosal surface and in the invaginated epithelial lining of the intestinal crypts. Mucins are classified according to their ability to form a gel, namely gelforming (secreted) or non-gel-forming (membrane-bound) mucins (Devine and McKenzie, 1992). Mucins are also classified into neutral or acid mucins, according to the net charge of the molecule. Acid mucins are further differentiated based on their histochemical properties into sulfate-containing mucins (sulfomucins) and sialicacid-containing mucins (sialomucins) (Filipe, 1979). The mucin oligosaccharides in the mucous gel represent a direct source of peptides, carbohydrates, and nutrients that allow the colonization of 
bacteria in the mucous layer of the GIT (Deplancke and Gaskins, 2001).

The distribution of gastrointestinal mucins can differ according to the number of secreting cells, cell type, anatomical region, pathological condition and species (Scillitani et al., 2007). The distribution of the various types of gi mucins has been determined histochemically in several mammalian species (Sheahan and Jervis, 1976; Filipe, 1979; Kotzé and Coetzee, 1994) and fish species (Tibbetts, 1997; Cao and Wang, 2009). However, there is still a need for a better understanding of the distribution of mucins in normal tissues (Hattrup and Gendler, 2008). Therefore, the distribution of mucins was examined in the intestinal tracts of three insectivorous mammals, namely: Acomys Spinosissimus (southern African spiny mouse), Crocidura cyanea (reddish gray musk shrew) and Amblysomus hottentotus (Hottentot golden mole). These animals belong to three different superorders viz. euarchontoglires, afrotheria and laurasiatheria respectively and are widely distributed throughout southern Africa (Mills and Hes, 1997; Wilson and Reeder, 2005; Beck et al., 2006). Although all three species consume a wide variety of insects such as ants, beetles, termites, spiders and earthworms, A. spinossisimus, the only rodent species examined, ingests mainly seeds in addition to insects (Vesey-Fitzgerald, 1966; Kingdon, 1974a,b; Perrin and Curtis, 1980; Dickman, 1995; Mills and Hes, 1997; Stuart and Stuart, 2001).

The aim of the present study was to document the distribution of mucin secreting goblet cells in the GITs of three insect eating mammalian species from different orders in order to indirectly provide insights about the quality of the protective biofilm on the internal surface of the GIT.

\section{Materials and methods}

\section{Animals}

Intact GI specimens, of animals that were previously fixed by perfusion with $4 \%$ paraformaldehyde, were obtained from the Department of Zoology and Entomology at the University of Pretoria. The GITs of A. spinosissimus $(n=5), C$. cyanea $(n=5)$ and $A$. hottentotus $(n=4)$ were made available for this study. Ethical clearance for the use of these specimens was obtained from the animal ethics committees of the Universities of Pretoria and Stellenbosch. Nature conservation permits were also obtained prior to commencement of this study.

\section{Harvesting of tissue and histochemical methods}

Tissue was harvested from corresponding GI regions in each species. In A. spinosissimus, samples were removed from the body of the stomach, duodenum, middle small intestine, ileum, caecum and colon. C. cyanea and A. hottentotus both lacked caeca, and macroscopically there was no clear differentiation between the small and large intestines. In the latter two species tissue was therefore harvested from the stomach, duodenum, and two areas corresponding to the presumed position of the middle and distal small intestines and colon. All tissue specimens were routinely processed to wax for histological examination.

Serial sections ( $4 \mu \mathrm{m}$ and $8 \mu \mathrm{m}$ thick) of the different regions of the intestines cut in cross section were mounted in sequence on four slides. Each of the four slides had four sections. Thus, sections on adjacent slides were in series and sections on the same slide were approximately 16-32 $\mu \mathrm{m}$ apart from each other. Slides were stained with alcian blue-periodic acid Schiff (AB-PAS) and aldehyde fuchsin-alcian blue (AF-AB). The slides containing $8 \mu \mathrm{m}$ thick sections were stained with high iron diamine-alcian blue (HIDAB). The combined AB-PAS technique (Mowry, 1956) was used to distinguish between neutral and acid mucins, whereas AF-AB (Spicer and Meyer, 1960) and HID-AB (Spicer, 1965) differentiated between sulfomucins and sialomucins. All the chemicals used to perform the staining techniques were obtained from Merck Chemicals (Pty.) Ltd. (Gauteng, RSA) and Sigma-Aldrich (Aston Manor, RSA).

In AB-PAS staining, neutral, acid and mixed neutral and acid mucins stain as magenta, blue and purple respectively. In AF-AB staining, sialomucins stain blue, mixed sulfo- and sialomucins stain blue/purple and sulfomucins stain purple. In HID-AB staining, sulfomucins stain black and sialomucins stain blue. Although both the $\mathrm{AF}-\mathrm{AB}$ and $\mathrm{HID}-\mathrm{AB}$ staining techniques distinguish between sulfomucins and sialomucins, the $A F-A B$ technique can further distinguish between strongly sulfated (deep purple) and weakly sulfated (light purple) mucins (Bancroft and Gamble, 2008). Two sections (at least $16-32 \mu \mathrm{m}$ apart) were selected for histological examination, and photographed with a Zeiss Axioskop2 light microscope fitted with a Zeiss color camera and Axiovision software. Photographs were taken using the $2.5 \times$ and $20 \times$ objective lenses. Images were taken at low magnification to produce a photograph of the whole tissue section. Multiple images were captured at high magnification to produce composite images of a field of view, by merging images together using Hugin software (version 2011.0.0.0fd3e119979c). These images were photographed in a systematic way by capturing every second field of view across the entire length of the tissue section.

\section{Measurement and quantification protocol}

Image analysis software, NIS Elements Basic Research (Version 3.10), was used to measure the following parameters from each of the stained sections: The total length of each tissue section in $\mathrm{mm}$ was measured from the micrographs captured using the $2.5 \times$ objective lens. The length of the tissue ( $\mathrm{mm}$ ), the surface epithelial and crypt areas $\left(\mathrm{mm}^{2}\right)$ and quantification of goblet cells were determined using images taken at higher magnification $(20 \times$ objective). The systematic approach used to capture images from two tissue sections on each slide ensured that at least $50 \%$ of the tissue was analyzed. For each region of the GIT (except the stomach) the area covered by epithelial cells lining the surface and crypts was delineated and measured, and the number of goblet cells was quantified in each of these regions. The data were expressed as the total number of mucin specific goblet cells counted in the surface epithelial- and crypt areas $\left(\mathrm{mm}^{2}\right)$ respectively, as well as in the sum of the areas covered by the surface epithelium and crypt areas $\left(\mathrm{mm}^{2}\right)$. Mucous secreting cells of the stomach and Brunner's glands were not quantified owing to the difficulty of distinguishing between individual cells and thus only the staining characteristics are described.

\section{Statistical data analysis}

Statistical analyses were performed using the Statistica data analysis software system, version 10 (StatSoft, Inc. Tulsa, OK, USA) The number of goblet cells $/ \mathrm{mm}^{2}$ for each GI region was analyzed using the F-test ANOVA and Fisher's Least Significant Difference (LSD) test. Statistical significance was determined at $p \leq 0.05$ and a $p$-value $\leq 0.01$ is regarded as highly significant. From here on statistically significant results will be referred to as significant.

The intestinal regions portrayed on the graphs were the duodenum, middle and distal small intestines and the large intestine. The large intestine of $A$. spinosissimus comprises the caecum and the colon. The labeling of the intestinal regions on the graphs was done in such a manner as to compare A. spinosissimus with the species without caeca. 


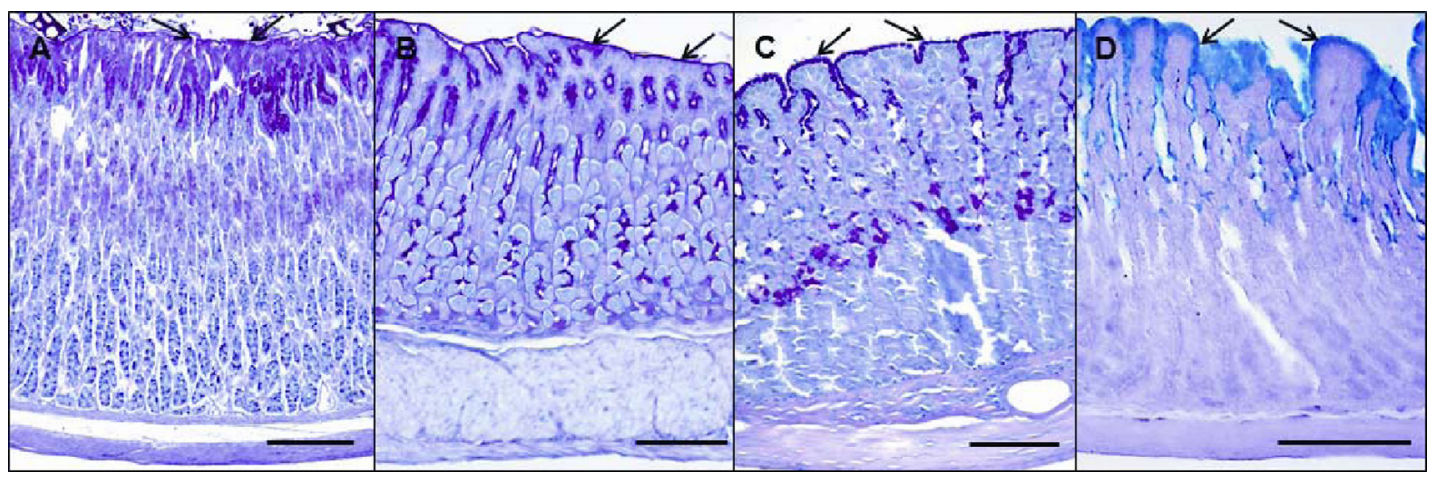

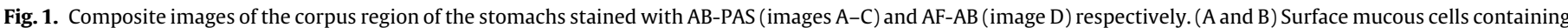

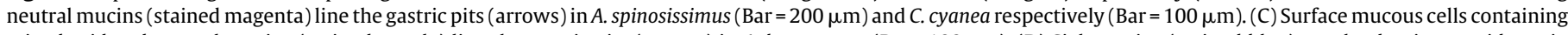

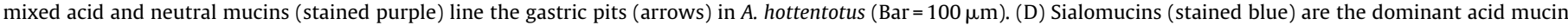

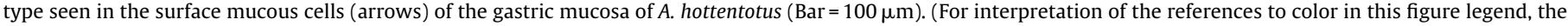
reader is referred to the web version of this article.)

\section{Results}

\section{Descriptive results for the stomach and Brunner's glands}

Mucous cells in the body (corpus) of the stomach of all three insectivorous species contained predominantly neutral mucins. Neutral mucins in the corpus mucous neck cells of $A$. spinosissimus (Fig. 1A) stained less intensely than the surface mucous cells, while a small number of mucous neck cells were weakly stained for either sulfomucins or sialomucins. Acid mucins were not observed in the stomach of $C$. cyanea, while strongly stained neutral mucins were present in the surface mucous cells and the mucous neck cells (Fig. 1B). In A. hottentotus, the surface mucous cells and the proximal mucous neck cells of the gastric glands consisted of mixed mucins (neutral and acid), whereas the distal mucous neck cells stained intensely for neutral mucins (Fig. 1C). Intensely stained sialomucins were present in surface and neck mucous cells of $A$. hottentotus, while few mixed sialomucins and sulfomucins were present in the corpus of the stomach (Fig. 1D). Brunner's glands (mucous secreting glands) were present in the submucosa of the duodenum in all three species and the glands contained predominantly neutral mucin granules. However, in A. hottentotus, mucous secreting cells of the Brunner's gland ducts contained both neutral and sialomucin granules.

\section{Quantification of mucin secreting goblet cells}

\section{AB-PAS technique}

The total number of goblet cells per total area $\left(\mathrm{mm}^{2}\right)$ quantified with the AB-PAS technique illustrates the overall distribution of the neutral and acid mucin secreting goblet cells throughout the GITs of all three insectivorous species (Fig. 2A). Both the surface epithelial and crypt areas revealed similar trends to that observed in Fig. 2A. With the exception of $C$. cyanea, the largest number of goblet cells was located mainly in the crypt areas (Table 1 ). The overall trend (Fig. 2A) shows that the number of goblet cells increased significantly towards the distal regions of the gut $(p<0.01)$ with $A$. hottentotus having significantly fewer goblet cells than $C$. cyanea $(p<0.01)$.

The total number of neutral mucin-containing goblet cells is significantly greater throughout the intestinal tract of $C$. cyanea than in the other two species $(p<0.01)$ (Fig. 2B) and this trend is similar for both the surface epithelium and crypt regions (Table 1). There is no significant difference in the number of neutral mucincontaining goblet cells between $A$. hottentotus and $A$. spinosissimus. Throughout the intestinal tracts of all three insectivorous species, similar numbers of neutral mucins were observed in the surface epithelial and crypt areas (Table 1). Except for A. hottentotus, a decrease of the neutral mucins was observed in both the surface epithelial and crypt areas of the large intestine. In A. hottentotus, the number of neutral mucins in the surface epithelial area increased towards the large intestine with a simultaneous decrease of cells in the crypts. C. cyanea has significantly fewer acid mucin-containing cells throughout the gut (Fig. $2 \mathrm{C}$ and Table 1 ) than in the other two species $(p<0.01)$ with $A$. hottentotus containing significantly greater numbers of these cells than $C$. cyanea and $A$. spinosissimus $(p<0.01)$ (Fig. 2C and Table 1). Goblet cells containing a mixture of neutral and acid mucins are the predominant type in all species (Fig. 2D and Table 1). Apart from in A. hottentotus, the distribution of the mixed mucins in the surface epithelial and crypt areas of the GIT revealed a similar pattern than observed in Fig. 2D. The crypt areas in A. hottentotus showed a decrease of cells from the duodenum to the large intestine.

\section{AF-AB and HID-AB techniques}

The results of the AF-AB and HID-AB techniques revealed that $A$. spinosissimus and $C$. cyanea had the largest number of acid mucins distributed throughout their GITs however, this result was not significant. Similar distribution patterns of the acid mucins were observed for both stains with quantitative differences in each GI region. The overall trend in all three species indicated that the number of acid mucins increased significantly $(p<0.01)$ towards the distal GI regions (Fig. 3A), with the largest number of cells in the crypt areas (Tables 2 and 3 ).

A. hottentotus had significantly more $(p<0.01)$ sialomucin secreting goblet cells than A. spinosissimus and $C$. cyanea (Fig. 3B), whereas $C$. cyanea had significantly more $(p<0.01)$ sulfomucin secreting goblet cells than the other insectivores (Fig. 3C). Uniform numbers of sialomucin secreting goblet cells were observed in the surface epithelial and crypt areas of the proximal GI regions of $A$. spinosissimus, followed by a significant decrease $(p<0.01)$ of cells in the large intestine (Fig. $3 \mathrm{~B}$ ). $C$. cyanea had predominantly sialomucin secreting goblet cells in the duodenum and few in the rest of the GIT, whereas in A. hottentotus large numbers of sialomucin goblet cells were present throughout the surface epithelial and crypt areas of the GIT. Both A. spinosissimus and C. cyanea had large numbers of sulfomucins, whereas $A$. hottentotus had comparatively few sulfomucins (Fig. 3C, Tables 2 and 3). C. cyanea had relatively equal numbers of both weakly and strongly sulfated goblet cells (Table 2) which revealed a similar distribution pattern than the overall trend seen in Fig. 3C. In A. spinosissimus weakly sulfated goblet cells were considerably more abundant than strongly 


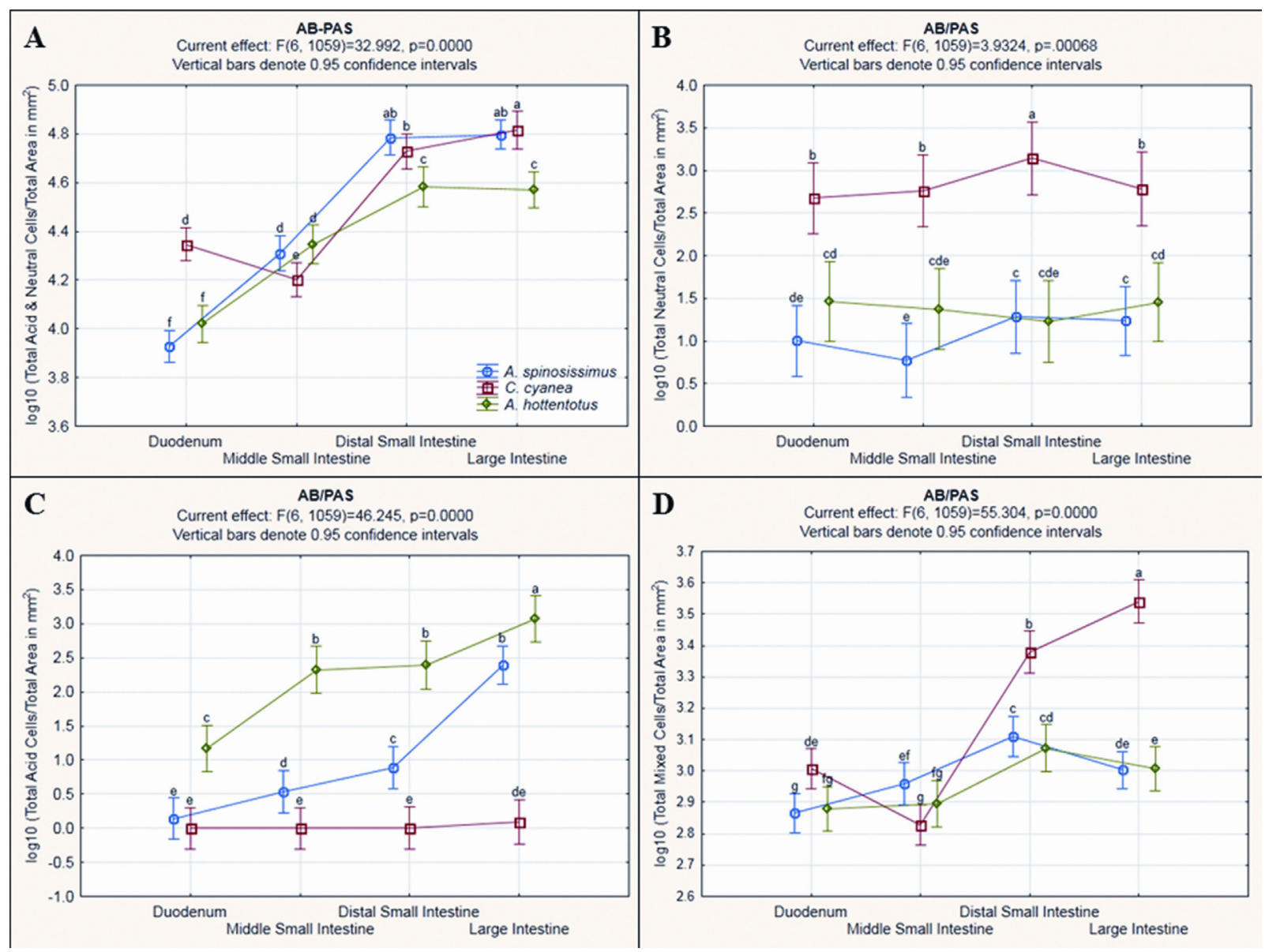

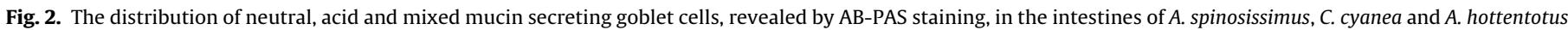

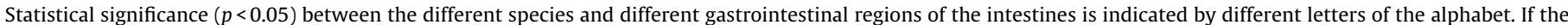

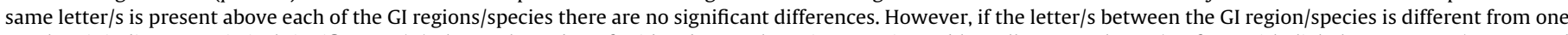

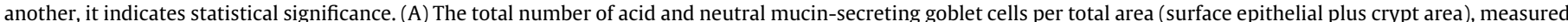

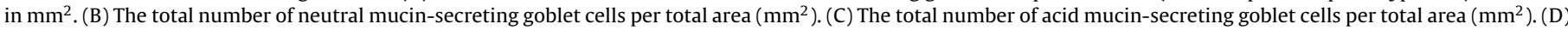

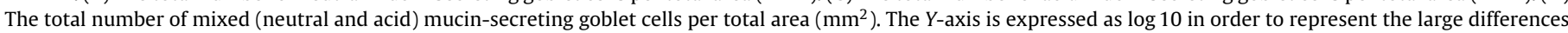
in goblet cell number between the different regions and species on the same graph.

sulfated goblet cells throughout the GIT. Goblet cells containing a mixture of sulfomucins and sialomucins were abundant in all three insectivores (Fig. 3D) however, the AF-AB stain revealed that $A$. hottentotus had predominantly more sialomucins than mixed acid mucins (Table 2).

\section{Discussion}

In all the mammalian species (mouse, rat, hamster, gerbil, guinea pig, rabbit, cat, dog, rhesus monkey, baboon and human) examined by Sheahan and Jervis (1976), neutral mucins were the

Table 1

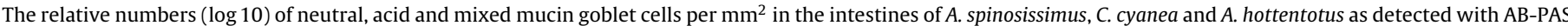
staining.

\begin{tabular}{|c|c|c|c|c|c|c|c|c|c|c|}
\hline \multirow[t]{2}{*}{ Species } & \multirow[t]{2}{*}{ GI region } & \multicolumn{3}{|c|}{ Total cells/epithelial area } & \multicolumn{3}{|c|}{ Total cells/crypt area } & \multicolumn{3}{|c|}{ Total cells/area } \\
\hline & & Neutral & Acid & Mixed & Neutral & Acid & Mixed & Neutral & Acid & Mixed \\
\hline \multirow{4}{*}{ A. spinosissimus } & Duodenum & 0.44 & 0.00 & 2.76 & 1.06 & 0.16 & 2.97 & 1.00 & 0.14 & 2.87 \\
\hline & Middle small intestine & 0.67 & 0.40 & 2.87 & 0.70 & 0.53 & 3.04 & 0.77 & 0.54 & 2.96 \\
\hline & Distal small intestine & 1.17 & 0.26 & 3.06 & 1.10 & 1.00 & 3.07 & 1.27 & 0.85 & 3.11 \\
\hline & Large intestine & 1.03 & 0.30 & 2.87 & 0.97 & 2.54 & 2.98 & 1.24 & 2.39 & 3.00 \\
\hline \multirow{4}{*}{ C. cyanea } & Duodenum & 2.52 & 0.00 & 3.03 & 2.70 & 0.00 & 2.95 & 2.67 & 0.00 & 3.01 \\
\hline & Middle small intestine & 2.73 & 0.00 & 2.91 & 2.82 & 0.00 & 2.65 & 2.76 & 0.00 & 2.83 \\
\hline & Distal small intestine & 3.14 & 0.00 & 3.45 & 2.96 & 0.00 & 3.00 & 3.08 & 0.00 & 3.38 \\
\hline & Large intestine & 2.61 & 0.10 & 3.61 & 2.79 & 0.00 & 3.33 & 2.78 & 0.09 & 3.54 \\
\hline \multirow{4}{*}{ A. hottentotus } & Duodenum & 1.33 & 1.24 & 2.79 & 1.09 & 0.46 & 3.02 & 1.46 & 1.17 & 2.88 \\
\hline & Middle small intestine & 0.81 & 2.31 & 2.89 & 1.46 & 1.27 & 2.85 & 1.37 & 2.32 & 2.90 \\
\hline & Distal small intestine & 1.16 & 2.14 & 3.19 & 1.29 & 2.55 & 2.82 & 1.23 & 2.39 & 3.07 \\
\hline & Large intestine & 1.60 & 1.98 & 3.15 & 1.05 & 3.20 & 2.83 & 1.46 & 3.07 & 3.01 \\
\hline
\end{tabular}

Regions that have less than 0.001 cells $/ \mathrm{mm}^{2}$ are stated as 0.000 in the table. 

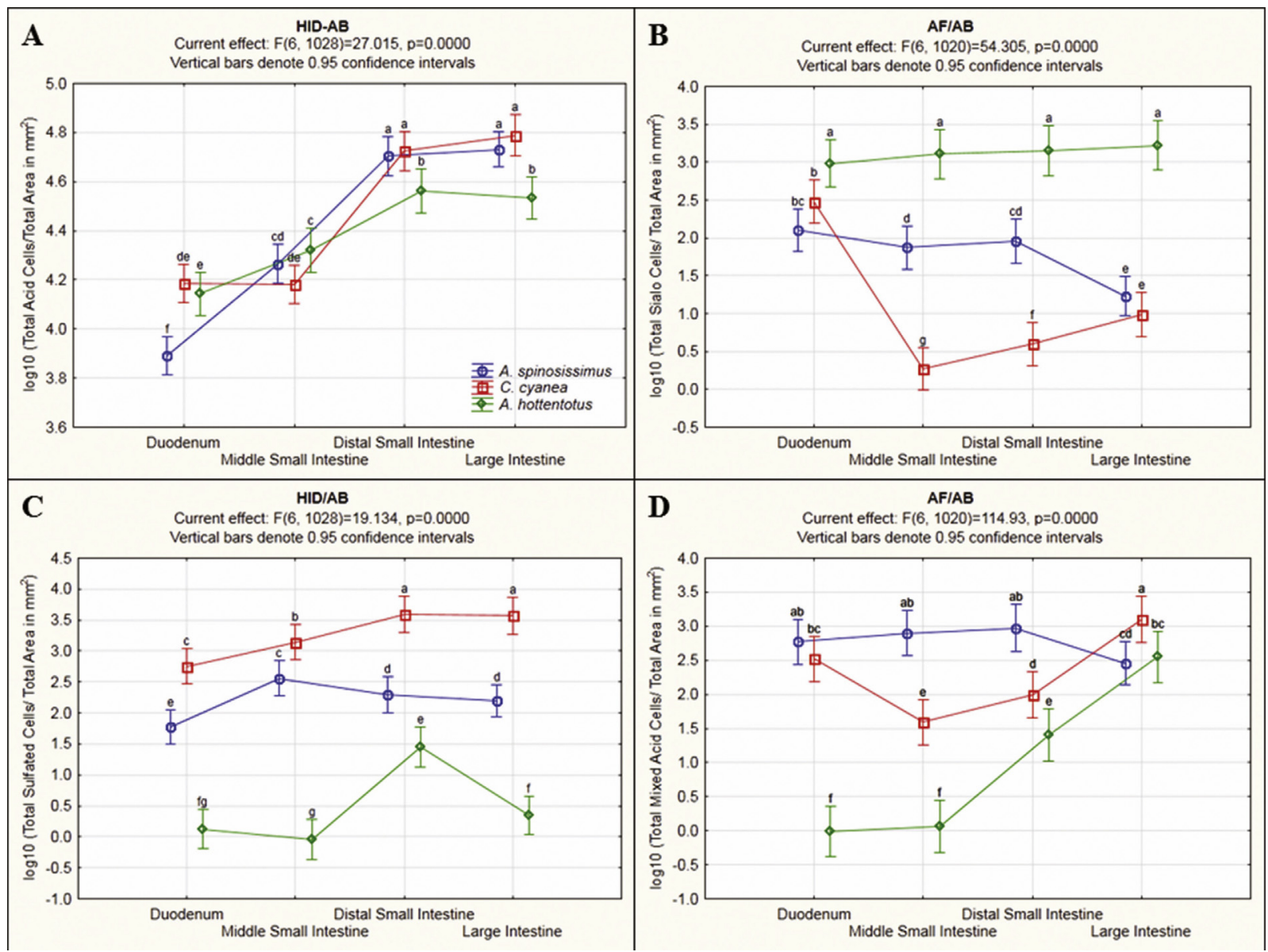

Fig. 3. The distribution of sialomucin and sulfated mucin secreting goblet cells, revealed by HID-AB and AF-AB staining, in the intestines of A. spinosissimus, C. cyanea and A. hottentotus. Statistical significance $(p<0.05)$ between the different species and different gastrointestinal regions of the intestines is indicated by different letters of the alphabet. If the same letter/s is present above each of the GI regions/species there are no significant differences. However, if the letter/s between the GI region/species is different from one another, it indicates statistical significance. (A) The total number of acid mucin (sialo- and sulfomucin) secreting goblet cells per total area (surface epithelial plus crypt area), measured in $\mathrm{mm}^{2}$. (B) The total number of sialomucin secreting goblet cells per total area $\left(\mathrm{mm}^{2}\right)$. (C) The total number of sulfomucin secreting goblet cells per total area $\left(\mathrm{mm}^{2}\right)$. (D) The total number of mixed (sialo- and sulfomucin) mucin secreting goblet cells per total area $\left(\mathrm{mm}^{2}\right)$. The $Y$-axis is expressed as log 10 in order to represent the large differences in goblet cell number between the different regions and species on the same graph.

predominant type expressed throughout the entire gastric epithelium. These authors examined the different types of mucins in three stomach regions (cardia, corpus and pyloric antrum) and found that the mucous cells in the deep cardiac glands and the mucous neck cells in the corpus and pyloric antral glands did not stain as intensely neutral as the mucous cells on the gastric surface. In contrast, in the present study, the neutral mucins in the corpus mucous neck cells of $A$. spinosissimus stained slightly weaker than those of the surface mucous cells while strongly stained neutral mucins were present in the mucous neck cells of $C$. cyanea. Sheahan and

Table 2

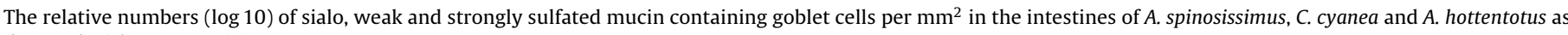
detected with AF-AB staining.

\begin{tabular}{|c|c|c|c|c|c|c|c|c|c|c|c|c|c|}
\hline \multirow[t]{2}{*}{ Species } & \multirow[t]{2}{*}{ GI region } & \multicolumn{4}{|c|}{ Total cells/epithelial area } & \multicolumn{4}{|c|}{ Total cells/crypt area } & \multicolumn{4}{|c|}{ Total cells/area } \\
\hline & & Sialo & $\begin{array}{l}\text { Weak } \\
\text { Sulfo }\end{array}$ & $\begin{array}{l}\text { Strong } \\
\text { Sulfo }\end{array}$ & Mixed & Sialo & $\begin{array}{l}\text { Weak } \\
\text { Sulfo }\end{array}$ & $\begin{array}{l}\text { Strong } \\
\text { Sulfo }\end{array}$ & Mixed & Sialo & $\begin{array}{l}\text { Weak } \\
\text { Sulfo }\end{array}$ & $\begin{array}{l}\text { Strong } \\
\text { Sulfo }\end{array}$ & Mixed \\
\hline \multirow{4}{*}{ A. spinosissimus } & Duodenum & 1.38 & 1.50 & 0.31 & 2.59 & 2.17 & 1.81 & 0.16 & 2.85 & 2.10 & 1.91 & 0.34 & 2.77 \\
\hline & Middle small intestine & 1.20 & 2.22 & 0.43 & 2.76 & 1.90 & 2.21 & 0.22 & 2.95 & 1.87 & 2.39 & 0.49 & 2.90 \\
\hline & Distal small intestine & 1.40 & 2.51 & 0.44 & 2.87 & 1.95 & 2.30 & 0.17 & 3.04 & 1.96 & 2.47 & 0.45 & 2.98 \\
\hline & Large intestine & 0.77 & 1.30 & 1.03 & 1.87 & 1.20 & 2.54 & 1.38 & 2.47 & 1.23 & 2.49 & 1.44 & 2.46 \\
\hline \multirow{4}{*}{ C. cyanea } & Duodenum & 2.54 & 1.80 & 0.45 & 2.44 & 2.34 & 2.30 & 0.19 & 2.50 & 2.48 & 2.19 & 0.45 & 2.52 \\
\hline & Middle small intestine & 0.31 & 2.76 & 2.29 & 1.77 & 0.04 & 2.81 & 1.11 & 0.15 & 0.27 & 2.78 & 2.21 & 1.59 \\
\hline & Distal small intestine & 0.54 & 3.01 & 3.24 & 2.10 & 0.27 & 3.32 & 1.93 & 1.00 & 0.60 & 3.18 & 3.14 & 2.00 \\
\hline & Large intestine & 1.00 & 2.78 & 2.91 & 3.16 & 0.18 & 3.49 & 2.58 & 1.60 & 0.99 & 3.17 & 2.96 & 3.10 \\
\hline \multirow{4}{*}{ A. hottentotus } & Duodenum & 2.93 & 0.00 & 0.00 & -0.01 & 3.12 & -0.01 & 0.00 & -0.01 & 2.98 & -0.01 & 0.00 & -0.01 \\
\hline & Middle small intestine & 3.14 & 0.00 & 0.00 & 0.07 & 3.04 & 0.08 & 0.00 & 0.00 & 3.11 & 0.06 & 0.00 & 0.06 \\
\hline & Distal small intestine & 2.53 & 1.25 & 1.24 & 1.40 & 3.32 & 1.09 & 0.50 & 1.18 & 3.09 & 1.21 & 1.12 & 1.41 \\
\hline & Large intestine & 2.51 & 1.30 & 0.63 & 2.72 & 3.29 & 1.02 & 0.40 & 2.29 & 3.22 & 1.34 & 0.64 & 2.55 \\
\hline
\end{tabular}

Regions that have less than 0.001 cells $/ \mathrm{mm}^{2}$ are stated as 0.000 in the table. 
Table 3

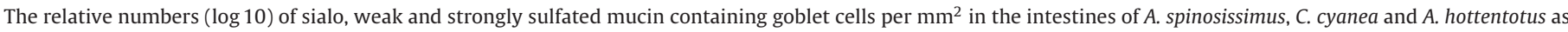
detected with HID-AB staining.

\begin{tabular}{|c|c|c|c|c|c|c|c|c|c|c|}
\hline \multirow[t]{2}{*}{ Species } & \multirow[t]{2}{*}{ GI region } & \multicolumn{3}{|c|}{ Total cells/epithelial area } & \multicolumn{3}{|c|}{ Total cells/crypt area } & \multicolumn{3}{|c|}{ Total cells/area } \\
\hline & & Sialo & Sulfo & Mixed & Sialo & Sulfo & Mixed & Sialo & Sulfo & Mixed \\
\hline \multirow{4}{*}{ A. spinosissimus } & Duodenum & 0.34 & 1.41 & 2.54 & 0.76 & 1.86 & 2.73 & 0.72 & 1.84 & 2.66 \\
\hline & Middle small intestine & 0.00 & 2.52 & 2.50 & 0.72 & 2.32 & 2.50 & 0.57 & 2.56 & 2.57 \\
\hline & Distal small intestine & 0.58 & 2.17 & 2.53 & 0.82 & 2.16 & 2.86 & 0.73 & 2.29 & 2.85 \\
\hline & Large intestine & 0.02 & 2.14 & 1.86 & 0.64 & 2.01 & 2.99 & 0.60 & 2.20 & 2.95 \\
\hline \multirow{4}{*}{ C. cyanea } & Duodenum & 0.36 & 2.68 & 1.96 & 0.23 & 2.72 & 1.80 & 0.35 & 2.75 & 1.91 \\
\hline & Middle small intestine & 0.00 & 3.17 & 0.09 & 0.00 & 2.99 & 0.06 & 0.00 & 3.14 & 0.09 \\
\hline & Distal small intestine & 0.14 & 3.64 & 0.18 & -0.01 & 3.43 & 0.03 & 0.13 & 3.60 & 0.17 \\
\hline & Large intestine & 0.00 & 3.56 & 0.09 & 0.00 & 3.69 & 0.02 & 0.00 & 3.48 & 0.09 \\
\hline \multirow{4}{*}{ A. hottentotus } & Duodenum & 2.61 & 0.13 & 2.55 & 2.93 & -0.06 & 1.13 & 2.78 & 0.12 & 2.45 \\
\hline & Middle small intestine & 2.64 & -0.05 & 2.69 & 2.26 & -0.03 & 2.10 & 2.71 & -0.04 & 2.64 \\
\hline & Distal small intestine & 1.94 & 1.51 & 2.75 & 1.72 & 1.31 & 3.07 & 2.06 & 1.45 & 2.94 \\
\hline & Large intestine & 2.66 & 0.47 & 3.07 & 3.13 & -0.01 & 2.23 & 3.11 & 0.35 & 2.84 \\
\hline
\end{tabular}

Regions that have less than 0.001 cells $/ \mathrm{mm}^{2}$ are stated as 0.000 in the table.

Jervis (1976) reported that sulfomucins were dominant in the stomachs of the rodent species (mouse, rat, hamster, gerbil and guinea pig) they examined. Of these rodent species, only the mouse, rat and guinea pig contained sialomucins in the stomach, where its distribution differed in each species: it was either present on the surface epithelium or in the deep glandular regions of the cardiac, corpus or pyloric areas. In contrast to these rodents, A. spinosissimus possessed only a small number of mucous neck cells, which stained weakly positive for sulfo- and sialomucins in the corpus of the stomach. A. hottentotus on the other hand had abundant sialomucins in the surface and neck mucous cells of the corpus stomach region, which is similar to that in the mouse, rat and guinea pig. No acid mucins were observed in the stomach of $C$. cyanea.

Emptying of the acidic stomach contents into the duodenum, along with gastric hydrochloric acid and proteases, creates a threat to the epithelial barrier of the duodenum (Moore et al., 2000). The secretion from Brunner's glands, along with pancreatic, bile and goblet cell secretions in the small intestine, neutralizes gastric hydrochloric acid (Takehana et al., 2000). Histochemical studies on the Brunner's glands of the rat, cat, dog, marmoset, marsupial mouse, bandicoot, native cat of eastern Australia, horseshoe bat and humans have shown that the duodenal glands mainly consist of neutral mucins (Sheahan and Jervis, 1976; Poddar and Jacob, 1979; Takehana et al., 2000). This is consistent with the observations made in the Brunner's glands of all three species in the present study. However, the gerbil, hamster, rabbit, horse, camel, baboon and rhesus monkey contained both sulfo- and sialomucins, along with neutral mucins, in the Brunner's glands (Sheahan and Jervis, 1976; Takehana et al., 1989, 2000) whereas in the African elephant, mainly sulfomucins and sialomucins were observed in the Brunner's glands (Kotzé and Coetzee, 1994). Mixed mucins, consisting of neutral and weakly stained sialomucins, were present in the Brunner's gland ducts of $A$. hottentotus and in a few irregularly positioned mucous cells in A. spinosissimus, which is comparable with the findings of Sheahan and Jervis (1976) for the mouse. Both acid and neutral mucins increase the viscosity of the mucous gel that protects the epithelial surface (Bansil and Turner, 2006) while additional acid mucins have been implicated in the protection of the mucosa against bacteria (Cao and Wang, 2009) and may play a similar role in the Brunner's gland secretions of the species studied here.

In the present study, mixed mucins (neutral and acid) appeared to be the predominant type present in the small and large intestines of all three insectivorous species. Despite the general trend of mixed mucin secreting goblet cells, there are marked differences between species in the qualitative expression of the mixed, neutral and acid mucin secreting goblet cells in each GI region.
These findings are in agreement with the conclusions of Sheahan and Jervis (1976) from their study on 11 mammalian species. The overall similarity between the three insectivores and other distantly related species such as primates and lagomorphs suggests that mixed mucin types are fundamental to the majority of mammals, irrespective of their diet or taxonomy.

Neutral mucin secreting goblet cells in the small intestines of A. spinosissimus and C. cyanea appeared to dominate over the acid mucin secreting goblet cells. However, in A. hottentotus the acid mucin secreting goblet cells were predominantly located in the small intestine. The small intestine of various animals (mouse, rat, hamster, guinea pig, rabbit and cat), examined by Sheahan and Jervis (1976), revealed that goblet cells secreting sulfomucins were more predominant than those secreting sialomucins. This correlates with the findings of $A$. spinosissimus and $C$. cyanea, however, in the gerbil (rodent); sialomucins were the main acid mucin present in the small intestine (Sheahan and Jervis, 1976). Similarly to the gerbil, A. hottentotus had large numbers of sialomucin secreting goblet cells in the duodenum and middle small intestine. Abundant sulfomucins and sialomucins were present in the small intestine of the dog (Sheahan and Jervis, 1976), and equal amounts of sulfomucins and sialomucins were present in the African elephant and the horseshoe bat, the latter being an insectivorous species (Kotzé and Coetzee, 1994; Scillitani et al., 2007). The sulfomucins detected in the GITs of the insectivorous species studied here were largely weakly sulfated. Some specific correlations have been observed between the rodent species in terms of the presence of sulfomucins in the small intestine; however interspecies variations were evident between the rodents and the insectivores of this study.

As in the small intestine, mixed (acid and neutral) mucins are the predominant type of mucin in the large intestine of the three insectivorous species of the present study. These findings correlate with the studies of Sheahan and Jervis (1976) and Kotzé and Coetzee (1994), but the abundance of the mixed mucins in the intestinal tracts of the examined species is not clear. The former authors observed that acid mucin secreting goblet cells were abundant in the intestinal epithelium, but most prominent in the large intestine, with a decrease of neutral mucins towards the large intestine. In view of the fact that large bacterial colonies are found in the large intestine, especially the colon (Macfarlane and Dillon, 2007), the increase of acid mucins suggests that the mucous gel viscosity is increased to better protect the surface epithelial layer.

Kotzé and Coetzee (1994) observed that there were slightly more sulfomucins than sialomucins in the large intestine of the African elephant. Sheahan and Jervis (1976) reported that sulfomucins are the main acid mucin type in all 11 mammals they 
examined. Similar observations were made in the present study in A. spinosissimus and C. cyanea; however A. hottentotus had substantially more sialomucins in the distal small intestine and colon. The state of GI protection against bacterial infection appears to be related to the degree of mucin maturation (Montagne et al., 2004). According to Van Leeuwen and Versantvoort (1999) mature mucins are primarily sulfated. The acidic mucins, sulfomucins and sialomucins, increase the ability of mucus to resist attack by bacteria and bacterial enzymes.

Despite the few general similarities between A. spinosissimus and $C$. cyanea, there are inter-species differences between the insectivores of this study. Marked differences were especially observed between the insectivores in the qualitative expression of the different mucins in each GI region. Similar observations were made by Sheahan and Jervis (1976). It is therefore difficult to determine whether the distribution of mucins is related to diet. The specimens used in this study were captured in the wild and none of the animals were subjected to a controlled diet. It is unclear to what extent a controlled diet would change the phenotypic expression of mucins in the GITs of the insectivore species studied here. Studies done by Sharma et al. (1993) and Sharma and Schumacher (1995) on germfree and conventional rats indicated that diet and microflora can influence both the secretory pattern of GI mucins and the mucosal architecture, as particularly neutral and sulfomucins secreting cells showed changes in the jejunum and proximal colon with response to diet and/or microflora. A diet that contains abrasive or high fiber food such as seeds, grasses and exoskeletons of insects, as is the case in the animals of this study, may allow for increased mucus production as the ingested abrasive food stuffs slough off the current mucous layer. The clearing of the mucous layer with the aid of high fiber foods may allow for increased intestinal protection in insectivores against pathogens as the defensive mechanism of mucins lies in their capability to entrap microbes (Deplancke and Gaskins, 2001) and then removing them from the gut through shedding of the mucous layer (Pearson and Brownlee, 2005; Linden et al., 2008).

\section{Conclusion}

Mucins have become an important element in the study of GI physiology, pathology and even taxonomy (Scillitani et al., 2007; Cao and Wang, 2009). The different types of mucins (neutral, sulfomucins and sialomucins) have also been implicated in the colonization of the biofilm in the GIT. The mucin oligosaccharides provide a source of carbohydrates and peptides which can supply bacteria with the necessary nutrients to improve colonization. In addition, mucins may function as epitopes with which bacteria can interact to colonize the mucosal layer (Deplancke and Gaskins, 2001). Therefore it is important to determine the composition of the different types of mucins in the mucosal layer, which affects the colonization of microflora. In the present study mixed (neutral and acid) mucins were found predominantly in the GITs of all three insectivores, whereas mixed acid (sulfomucins and sialomucins) mucins were most prominent in A. spinosissimus and large numbers of sulfomucins and sialomucins were present in $C$. cyanea and A. hottentotus respectively.

It is essential to understand the normal microbiome of the GIT in various species to provide a better understanding of the role of normal gut flora which is important for the maintenance of a healthy GIT. There are still many unanswered questions about the distribution, function and structure of mucins in health and disease. Therefore, a better understanding of mucins in normal tissues of a variety of species is needed, as most mucin studies have been performed on diseased tissue or cell lines (Hattrup and Gendler, 2008).

\section{Acknowledgments}

The authors thank Prof. M. Kidd, Centre for Statistical Consultation, University of Stellenbosch, for the statistical analysis, Reggie Williams and Morea Petersen for technical assistance and the Harry Crossley Foundation for funding this project. NCB acknowledges funding from the DST-NRF SARChI chair of Mammalian Behavioural Ecology and Animal Physiology.

\section{References}

Atuma C, Strugala V, Allen A, Holm L. The adherent gastrointestinal mucus gel layer: thickness and physical state in vivo. Am J Physiol Gastrointest Liver Physiol 2001;280:G922-9.

Bancroft J, Gamble M, editors. Theory and practice of histological techniques. Edinburgh, London: Churchill Livingston Elsevier Limited; 2008. p. 161-86.

Bansil R, Turner BS. Mucin structure, aggregation, physiological functions and biomedical applications. Curr Opin Colloid 2006;11:164-70.

Beck RM, Bininda-Emonds OR, Cardillo M, Lui FG, Purvis A. A higher-level MRP supertree of placental mammals. BMC Evol Biol 2006;13:93.

Cao XJ, Wang WM. Histology and mucin histochemistry of the digestive tract of yellow catfish, Pelteobagrus fulvidraco. Anat Histol Embryol 2009;38:254-61.

Corfield AP, Shukla AK. Mucins: vital components of the mucosal defensive barrier. Am Genomic/Proteomic Technol 2003;3:20-2.

Deplancke B, Gaskins HR. Microbial modulation of innate defense: goblet cells and the intestinal mucus layer. Am J Clin Nutr 2001;73:1131S-41S.

Devine PL, McKenzie IF. Mucins: structure, function, and associations with malignancy. Bioessays 1992;14:619-25.

Dickman CR. Diets and habitat preferences of three species of crocidurine shrews in arid southern Africa. J Zool (Lond) 1995;237:499-514.

Filipe MI. Mucins in the human gastrointestinal epithelium: a review. Invest Cell Pathol 1979;2:195-216.

Forstner J, Forstner G. Gastrointestinal mucus. In: Johnson L, editor. Physiology of the gastrointestinal tract, vol. 2, 3rd ed. New York: Raven Press; 1994. p. 1255-83.

Hattrup CL, Gendler SJ. Structure and function of the cell surface (tethered) mucins. Annu Rev Physiol 2008;70:431-57.

Kingdon J. East African mammals, an atlas of evolution in Africa, vol. II, Part A (insectivores and bats). London: Academic Press; 1974a. p. 19-27, 95-109.

Kingdon J. East African mammals, an atlas of evolution in Africa, vol. II Part B (hares and rodents). London: Academic Press; 1974b. p. 654-8.

Kotzé SH, Coetzee HL. A histocytochemical study of mucus glycoproteins or mucins in the intestinal tract of the African elephant (Loxodonta africana). Onderstepoort J Vet Res 1994;61:177-81.

Linden SK, Sutton P, Karlsson NG, Korolik V, McGuckin MA. Mucins in the mucosal barrier to infection. Mucosal Immunol 2008;1:183-97.

Macfarlane S, Dillon JF. Microbial biofilms in the human gastrointestinal tract. J Appl Microbiol 2007;102:1187-96.

McAuley JL, Linden SK, Png CW, King RM, Pennington HL, Gendler SJ, et al. MUC1 cell surface mucin is a critical element of the mucosal barrier to infection. J Clin Invest 2007;117:2313-24.

McGuckin MA, Every AL, Skene CD, Linden SK, Chionh YT, Swierczak A, et al. Muc1 mucin limits both Helicobacter pylori colonization of the murine gastric mucosa and associated gastritis. Gastroenterology 2007;133:1210-8. 
Mills G, Hes L. The complete book of Southern African mammals. Cape Town: Struik Winchester Publishers; 1997.

Montagne L, Piel C, Lallès JP. Effect of diet on mucin kinetics and composition: nutrition and health implications. Nutr Rev 2004;62:105-14.

Moore BA, Morris GP, Vanner S. A novel in vitro model of Brunner's gland secretion in the guinea pig duodenum. Am J Physiol Gastrointest Liver Physiol 2000;278:G477-85.

Mowry RW. Alcian blue techniques for the histochemical study of acidic carbohydrates. J Histochem Cytochem 1956;4: 407.

Pavelka M, Roth J. Functional ultrastructure: atlas of tissue biology and pathology. 2nd ed. Austria: Springer-Verlag/Wien; 2010.

Pearson J, Brownlee I. Structure and function of mucosal surfaces. In: Nataro J, Cohen P, Mobley H, Weiser J, editors. Colonization of mucosal surfaces. Washington, DC: ASM Press; 2005. p. 3-16.

Perrin MR, Curtis BA. Comparative morphology of the digestive system of 19 species of southern African myomorph rodents in relation to diet and evolution. S Afr J Zool 1980;15:22-33.

Poddar S, Jacob S. Mucosubstance histochemistry of Brunner's glands, pyloric glands and duodenal goblet cells in the ferret. Histochemistry 1979;65:67-81.

Probert HM, Gibson GR. Bacterial biofilms in the human gastrointestinal tract. Curr Issues Intest Microbiol 2002;3:23-7.

Raouf AH, Tsai HH, Parker N, Hoffman J, Walker RJ, Rhodes JM. Sulphation of colonic and rectal mucin in inflammatory bowel disease: reduced sulphation of rectal mucus in ulcerative colitis. Clin Sci (Lond) 1992;83:623-6.

Scillitani G, Zizza S, Liquori GE, Ferri D. Lectin histochemistry of gastrointestinal glycoconjugates in the greater horseshoe bat, Rhinolophus ferrumequinum (Schreber, 1774). Acta Histochem 2007;109:347-57.

Sharma R, Schumacher U. Morphometric analysis of intestinal mucins under different dietary conditions and gut flora in rats. Dig Dis Sci 1995;40:2532-9.
Sharma R, Schumacher U, Ronaasen V, Coates M. The effects of diet and human microbial flora on the morphology and carbohydrate composition of rat intestine. In: Pusztai A, Hinton M, Mulder R, editors. Prevention and control of potentially pathogenic organisms in poultry and poultry meat processing. Netherlands: Het Spelderholt; 1993. p. 109-16.

Sheahan DG, Jervis HR. Comparative histochemistry of gastrointestinal mucosubstances. Am J Anat 1976;146:103-31.

Spicer SS. Diamine methods for differentiating mucosubstances histochemically. J Histochem Cytochem 1965;13:211-34.

Spicer SS, Meyer DB. Histochemical differentiation of acid mucopolysaccharides by means of combined aldehyde fuchsinalcian blue stain. Tech Bull Regist Med Technol 1960;30:53-60.

Stuart C, Stuart M. Field guide to mammals of Southern Africa. Cape Town: Struik Publishers; 2001. p. 32, 42, 108.

Takehana K, Abe M, Iwasa K, Hiraga T. Histochemistry of complex carbohydrates in the horse duodenal gland. Nihon Juigaku Zasshi 1989;51:909-15.

Takehana K, Eerdunchaoluo, Ueda H, Kobayashi A, Iwasa K, Sou K. A histochemical study of the camel (Camelus bactrianus) duodenal glands. J Vet Med Sci 2000;62:449-52.

Tibbetts IR. The distribution and function of mucous cells and their secretions in the alimentary tract of Arrhamphus sclerolepis krefftii. J Fish Biol 1997;50:809-20.

Van Leeuwen P, Versantvoort CHM. Functional histology of the small intestinal mucosa in livestock production animals. In: Jansman AJM, Huisman J, editors. Nutrition and gastrointestinal physiology: today and tomorrow. Wageningen: TNO; 1999. p. 9-21.

Vesey-Fitzgerald D. The habits and habitats of small rodents in the Congo river catchment region of Zambia and Tanzania. Zool Afr 1966;2:111-22.

Wilson DE, Reeder DM. Mammals species of the world. In: A taxonomic and geographic reference. 3rd ed. Baltimore: Johns Hopkins University Press; 2005 http://www.press.jhu.edu 